\title{
High School Principals’ Experiences in Implementing HIV/AIDS Education Programs
}

\author{
Kennedy Ongaga \\ Missouri State University, 901 S. National Ave., Springfield, Missouri 65897, USA \\ *Email of the corresponding author: KennedyOngaga@MissouriState.edu \\ Mary Ombonga \\ Missouri State University, 901 S. National Ave., Springfield, Missouri 65897, USA
}

\begin{abstract}
Young people are at the center of the HIV/AIDS epidemic. However, they offer a window of hope in stemming the tide of HIV/AIDS if they are reached early by HIV/AIDS education programs, whose objective is to develop the awareness, knowledge, skills, attitudes and values that reduce infections. While school-based HIV/AIDS education is believed to encompass these programmatic skills, little is known about the role and experiences of principals who oversee their implementation. This paper, which is part of a larger study, uses the cultural frame to investigate the experiences of two high school principals regarding their role in implementing HIV/AIDS education programs in Kisii County, Kenya. Data were collected through interviews and participant observation. Findings show that culture, more than policy, influences the role principals play in implementing HIV/AIDS education programs. A principal who hails from the local community where the school is situated is less likely to implement HIV/AIDS education programs that go against the community's culture compared to one from outside. The study concluded that delocalization of principals has the potential of galvanizing the school organization to educate young people about actions they can take to protect themselves from becoming infected.

Keywords: HIV/AIDS Education, School-based AIDS Education, Principalship and HIV/AIDS, HIV/AIDS and Culture
\end{abstract}

DOI: $10.7176 / \mathrm{JEP} / 10-36-01$

Publication date: December $31^{\text {st }} 2019$

\section{Introduction}

Global HIV \& AIDS statistics from the Joint United Nations Programme on HIV/AIDS (UNAIDS) indicate that the pace of progress in reducing new HIV infections, increasing access to treatment and ending AIDS-related deaths has gained traction in the world (UNAIDS, 2019). According to UNAIDS (2018), 1.7 million people were newly infected with HIV in 2018, 37.9 million were living with HIV, and 770 thousand died of AIDS-related illness. In sub-Saharan Africa, four in five new infections among adolescents aged 15-19 years are girls. Young women aged 12-24 years are twice as likely to be living with HIV than men of the same age (UNAIDS, 2018). In a speech to German development officials in 2001, Calisto Madavo, the then World Bank Vice President for Africa, said of this tragic situation of figures:

Let us not be caught in numbers, HIV infection rates, HIV prevalence rates and mortality rates. Behind these numbers there is flesh and blood. Behind these numbers there are husbands, wives, parents, children, farmers, teachers, doctors. It's the wellspring of African knowledge and wisdom being drained before our eyes. According to a West African proverb, 'Every time an elder dies, it's as if a library has burned down ${ }^{1}$.

Statistics specific to Kenya (UNAIDS, 2019), show that in 2018:

- 1600000 people were living with HIV.

- HIV prevalence - the percentage of people living with HIV - among adults (15-49 years) was 4.7\%.

- 46000 people were newly infected with HIV, a decrease from 66000 since 2010.

- 25000 people died from an AIDS-related illness.

- $\quad 89 \%$ of people living with HIV knew their status.

- $68 \%$ of people living with HIV were on treatment.

Kisii county, the context of this study, has an overall prevalence rate of $4.4 \%$ (Male $4 \%$; female $4.7 \%$ ).

\section{HIV/AIDS and Education}

HIV/AIDS constitutes one of the biggest threats to the global education agenda. Evidence shows that it threatens to overwhelm the very fabric and structure of educational organizations, management, and provision of services

${ }^{1}$ Calisto Madavo, Vice President for Africa, World Bank, at an address to a gathering of German development officials in Berlin, March 29, 2001. 
as has traditionally been known (Kelly, 2000). However, educational systems have enormous potential that can help reduce the incidence of HIV/AIDS and alleviate its impact on society.

In Kenya HIV/AIDS is conceptualized as having the potential to negatively affect the education sector in terms of; (i) the demand for and supply of education, (ii) the quality and management of education, (iii) adjustments in response to the special needs of a rapidly increasing number of orphans as well as adaptation to new interactions both within and between schools and their communities (Gachuhi, 1999; Kelly, 2000; Siamwiza, 1999). Studies have shown that about $20 \%$ of the Kenyan student population (ages 15-24) is HIV infected, (Ministry of Health, 2001; Gachuhi, 2000). This calls for an urgent need for prevention methods with focused and intensified information dissemination about the disease among the youth and their communities.

In rural Kenya, the complexities of HIV/AIDS and preventive methods remain contested along patterns of shared cultural beliefs, social norms, religious morals, economic, and political divide (Gachuhi, 2000). According to Morgan (1997), these "patterns of belief or shared meaning, fragmented or integrated, and supported by various operating norms and rituals can exert a decisive influence on the overall ability of the organization to deal with the challenges that face it" (p.129). Indeed, schools are in the middle of such dilemma. In the absence of an HIV/AIDS vaccine, schools occupy a unique position of educating individuals about actions they can take to protect themselves from becoming infected or infecting other people. This argument is premised on the assumption that since the virus is transmitted exclusively by behavior that individuals can modify, HIV/AIDS education programs designed to influence relevant types of behavior can be effective in controlling the spread of the epidemic.

School-based HIV/AIDS education programs serve as guidelines for young people to understand the nature of the AIDS epidemic and the specific actions they can take to prevent HIV infection, especially during their adolescence and young adulthood (Ongaga \& Ombonga, 2018). Since HIV virus is predominantly spread through sexual contact, it is imperative for school systems to obtain broad community participation to ensure that school-based HIV/AIDS education programs and policies to prevent the spread of HIV are locally determined and are consistent with community values.

According to Coombe (2000) HIV/AIDS poses a twofold challenge for educational leadership. First, it undermines the very systems that should produce the needed leaders and all the support personnel and human capacity on which their effectiveness must rely. Second, it calls for creative, dynamic, visionary leadership that will inspire action and place education systems squarely in the forefront of the combat against HIV/AIDS. UNAIDS (2018) postulates that leading schools in the environment of HIV/AIDS is difficult; the cultural, social, economic, and political resources that can be brought to bear on the issue are more limited, and the demands of wide ranging social, attitudinal, and political change are more considerable. In such environments, key issues for school leaders revolve around engagement in advocacy, policy dialogue, publicity, networking, human rights issues, and resource mobilization.

Coupled with the view of sexuality and by extension HIV/AIDS as taboo subjects among most rural communities in Kenya, rural schools are caught in a dilemma on how best to respond and communicate on matters related to HIV/AIDS congruent with professional guidelines and their communities' patterns of beliefs, social and cultural orientations. In the context of HIV/AIDS, an unchallenged culture of silence can only serve to exacerbate the AIDS epidemic and increase confusion, denial, discrimination, stigmatization, and gender inequality (Ongaga \& Ombonga, 2018).

\section{School-based HIV/AIDS Programs: Whose Responsibility?}

Research (e.g., Bollinger et al., 2004; Kirby et al., 1994; Shuey et al., 1999; Kelly, 2000; Coombe, 2001; World Bank, 2002; Gachuhi, 1999; UNAIDS, 2000) suggested that many children could be saved if HIV education and prevention was mainstreamed in schools and universal primary completion was used to underpin an expanded prevention strategy. HIV/AIDS education should begin when children are young, before they get involved in any form of sexual activity, which may render them vulnerable (Black \& Jones, 1988; Kirby et al., 1991; Kelly, 2000; White \& Ballard, 1993).

Reinforcing clear values against risky behavior and strengthening individual values and group norms are therefore central to HIV/AIDS prevention programs (Kirby, 1994). Such reinforcement may require involving parents in the process of development, implementation and monitoring of school-based HIV/AIDS education and to serve as a strategy to diminish or manage potential conflicts. Unfortunately, this strategy is seldom used (Haignere et al., 1996; Schenker \& Greenblatt, 1993). Since parents culturally find it difficult to communicate with their children about sex and sexuality-related matters (Gachuhi, 1999; Kelly \& Parker, 2002) there is no choice but to turn to formal sources such as school-based education (Postrado \& Nicholson, 1992; Boler et al., 2003).

In Kenya, it is worth noting that young people growing up in rural and urban areas live in very different contexts. Youths in urban areas may experience relative freedom compared to their rural counterparts, where hierarchies of family and community frames attempt to regulate all sexual activity, (Boler \& Angleton, 2005). 
Regardless of their setting, youths' attitudes and behavior are deeply influenced by the culture, values, economic conditions, and the social political environments in which they live. School environments are therefore crucial determinants that account for youth behavior.

In most schools across sub-Saharan Africa, there has been concern that teachers do not act as positive role models for young people, and that their own sexual behavior is in direct contradiction to the behavior that is advocated for in HIV/AIDS education (Bennell, et al., 2002; Bennel, 2003; Gachuhi, 1999; Boler et al., 2003). This observation is reflected in Boler et al. (2003) study where $24 \%$ of student participants in Kisumu district, Kenya reported, "teachers did not set good role models when it comes to sexual behavior" (p.8). Consequently, the study recommends, "school must be a safe place for all students, and teachers who sexually harass students or enter into sexual relations with students, must be openly prosecuted," (p.49). Boler's study, however, did not probe the principals' role to understand how they handle such cases. The study recommended that "principals should be targeted, and they themselves be the focus on an educational process, so that they are in a better position to support HIV/AIDS education in schools," (p.49). For the most part in rural Kenya, it is reasonable to assume that it is the principal's responsibility to facilitate the creation of a safe environment where HIV/AIDS prevention messages are consistent and coherent across the school community. Thus, seeking to influence behavior alone is insufficient if the underlying social factors that shape the behavior remain unchallenged.

Haffner (1996) argued that given the nature of HIV/AIDS and the controversy surrounding its discussion particularly in rural settings, targeted interventions could be complemented by reaching out to a wider audience than those considered at risk, and changing the social consensus of the larger communities in which youth are embedded. This will require that "educators must of necessity move from a narrow 'HIV education' curriculum campaign towards a broader 'HIV and education' paradigm... The pandemic-as-phenomenon is vastly complex, and individual educators, researchers, policy makers and analysts, planners and funders each confront this plague from a different perspective, based on experience and training" (Coombe, 2002 p. xiii). Implementation of HIV/AIDS education programs will "require not only community involvement and dedicated, committed personnel, but also detailed planning at all levels, close coordination of the program implementation efforts, careful training and supervision of personnel, and continuous evaluation of program development and impact" (Fisher \& Foreit, 2002, p. 1).

HIV/AIDS education is also the responsibility of children, all school-going children. In their study on the impact of HIV/AIDS on education in Kenya, Ennew, et al. (2000) recommend that listening to children's voices is important in HIV/AIDS project design, implementation, and evaluation. By so doing, "communities and institutions working with children suffering psychosocial impacts as a result of HIV/AIDS will be sensitized on the needs of these children" (p.130). Recent studies done on behalf of the Economic Commission for Africa on the impact of the epidemic on education in a number of African countries including Kenya (UNECA, 2017) indicated that, most schools in rural sub-Saharan Africa are known for providing an authoritarian list of "dos and don'ts" with a view to motivating the youth to adopt sexually safe behavior. The study concluded that such approaches, which are characteristic of methods in a traditional school setting, may fail to speak to young people because, "they do not share the potential of non-formal approaches to enter into dialogue with the underlying cultural imperatives, which motivate young people from within more powerfully than anything the educator may propose from without" (Person \& Marin, 1988, p.34).

\section{Theoretical Framework}

This study sought to investigate two school principals' experiences in implementing HIV/AIDS education programs. The study is anchored in the cultural frame (Bolman \& Deal, 2017), which focuses on how humans use meaning, belief and faith to create culture. According to Bolman and Deal (2017) the cultural frame, distills ideas from diverse sources into five suppositions:

- What is most important is not what happens but what it means.

- Activity and meaning are loosely coupled; events and actions have multiple interpretations as people experience situations differently.

- In the face of uncertainty and ambiguity, symbols arise to help people resolve confusion, find direction, and anchor hope and faith.

- Events and processes are often more important for what they express or signal than for their intent or outcomes. Their emblematic form weaves a tapestry of secular myths, heroes and heroines, rituals, ceremonies, and stories to help people find purpose and passion.

- Culture forms the superglue that bonds an organization, unities people, and helps an enterprise to accomplish desired ends (pp. 241-242).

Goodenough 1971 (as cited in Patton, 2002), defined culture as "that collection of behavior patterns and beliefs that constitute "standards for deciding what is, standards for deciding what can be, standards for deciding how one feels about it, and standards for deciding how to go about it" (p.81). School culture therefore may reflect and express the values or social ideals and beliefs that pervade their communities. These values or 
patterns of beliefs can be manifested by symbolic devices, rituals, myths, and specialized language used in the context of HIV/AIDS. From a cultural approach, UNESCO and UNAIDS (2002) show that the interpretation of HIV infection as punishment involves holding sufferers "culpably responsible for their sickness". Rooted in ageold explanatory theories according to which disease is caused by breaking "taboos", an act punishable by supernatural powers, this rationale regards AIDS as the consequence of a failure to observe social norms and patients as guilty persons who have been "punished" and have to bear the consequences of their reprehensible behavior. Because of its links with behavior relating to sex and blood, both carrying high symbolic charges, HIV infection particularly lends itself to this interpretation legitimizing rejection and condemnation. Hence, fear of discrimination and stigma may cause people to shun screening tests and prompt those infected with and affected by HIV/AIDS to remain silent and deprive themselves of essential treatment and social care and concern.

From an organizational perspective, "culture induces purpose, commitment and order; provides meaning and social cohesion and clarifies and explains behavioral expectations. Through the people within it, "culture influences the organization" (Masland, 1985). Culture also can be understood as "a set of solutions devised by a group of people to meet specific problems posed by situations they face in common (Van Manen \& Barley, 1985, p. 33). In this sense culture consists of a set of behaviors and rules, which give a shared significance to common experiences and problems. Educational leaders in school organizations therefore are expected to learn to create psychological spaces for genuine exploration of difference, initiate conversations where problems and challenges may be identified and discussed and create a climate in which staff and students feel safe in clarifying their assumptions to deal with cultural dissonance (Brown, 2004). Culture has the power to entrap or overwhelm school principals' resourcefulness, strength, and courage to support the implementation of HIV/AIDS education programs.

\section{Research Methods}

This study sought to understand the principals' experiences in implementing HIV/AIDS education programs in 2 high schools in rural Kisii County, Kenya. We examine their role in implementing HIV/AIDS education programs and the challenges they face in executing this responsibility. Central to understanding their role was the understanding of how they influence or get influenced by stakeholders' ideologies, values, beliefs, language, norms, ceremonies, and other social practices that ultimately create, shape, and guide shared meanings in the implementation process.

We utilize a qualitative methodology with an ethnographic approach to answer the research question. According to Locke, et al. (2000), qualitative approach assumes that all persons construct their individual subjective accounts of each event in which they are participants. "Those subjective constructions are accepted as the realities of the social world. Thus, what is real is regarded as invariably multiple and immutably relative to person and context" (p. 96). Reality and/or experience in qualitative approach is socially constructed, complex, and ever changing (Glesne, 1999; Greene \& Hogan, 2005; Peshkin, 1986) and there is an intimate relationship between the researcher and the researched and the situational constraints that shape inquiry (Stainback \& Stainback, 1988). Therefore, understanding what people value and the meanings they attach to experiences, from their own personal and cultural perspectives, are major inquiry arenas for qualitative inquiry (Patton, 2002; Creswell, 1998).

Qualitative approach allows a researcher to seek answers regarding the "how" and "what" of a topic, and provide a mechanism for exploration into an uncharted question on a detailed level ( Yin, 2003; Patton, 2002; Lincoln \& Guba, 1985; Merriam, 1998; Miles \& Huberman, 1994; Denzin \& Lincoln, 2000; Glesne, 1999). This approach allows one to "inquire about specific social processes or particular persons' perspectives through direct contact with those involved - observing, interacting, and asking questions - in natural contexts where people function" (Locke, et al., 2000, p.97). Qualitative approach then "implies a direct concern with experience as it is 'lived' or 'felt' or 'undergone' as the aim of understanding experiences as nearly as its participants feel it or live it" (Sherman \& Webb, 1988, p. 7). These tenets were consonant to the aim of this study, to understand and articulate the experiences of principals regarding the implementation of HIV/AIDS education programs.

\section{Study Sample}

Data for this study was based on two high school principals (see Table 1), who were purposefully selected. According to Patton (2002), "the logic and power of purposeful sampling lies in selecting information-rich cases for study in depth. Information-rich cases are those from which one can learn a great deal about issues of central importance to the purpose of the research" (p.169). We utilized snowball or chain sampling strategy, which "identifies cases of interest from people who know people who know what cases are information-rich" (Miles \& Huberman, 1994, p. 28).

Principals are information-rich in understanding the context upon which implementation of school-based HIV/AIDS education programs take place. In rural Kenya, principals are respected leaders. They are assumed to be knowledgeable and in times of crises, believably, they possess the moral authority that can enable students, 
teachers, and the local community to challenge their own assumptions, clarify and strengthen their own values, and work on aligning their own behaviors and practice. Principals are also believed to have the skills to interpret and implement school programs including HIV/AIDS education programs and related policies. They are the embodiments of morals and their leadership an enactment of values in the local settings. Hence, they have the competence, a repertoire of vocabulary, skills, and knowledge necessary to engage in substantive discussions concerning HIV/AIDS both at school and in the community.

\section{Interview}

We utilized interviews and participant observation as the main avenues for collecting data. Interview is regarded not only as a tool of data gathering but also as an active interaction between two (or more) people leading to negotiated contextually based results (Fontana \& Frey, 2000). Qualitative studies indicate that the purpose of research interview is first and foremost to gather data, not to change people (Patton, 2002; Creswell, 1998; Kvale, 1996; Glesne, 1999). Thus, in striving to come closer to understanding people's meanings and their situations with increasing clarity, the interviewer learns from them as informants and seeks to discover how they organize their behavior (Bogdan \& Biklen, 2003; Spradley, 1979).

Additionally, we used unstructured open-ended interviews with the aim of getting participants to share their experiences, feelings, opinions, and knowledge (Patton, 2002) related to the implementation of HIV/AIDS programs in their schools. Each interview took approximately 60 minutes. During the interview process, participants became meaning makers and not passive conduits for retrieving information. This experience is in line with Gubrium and Holstein (2002) observation, that the purpose of qualitative interviewing is to derive interpretations, not facts or laws, from participants. Mills (2002) says that open-ended interviews allow the researcher and the researched to establish a link of openness and engagement that "speaks to the difference between gaining mere data and understanding a person's life experiences" (p.107). In probing for clarity, I learned how to balance the value of a potential response against the potential distress for the participants. I embraced the view that the art of interviewing entails framing questions in a way that allows interviewees to maintain their dignity while they tell the stories that are important to them. As the interviews evolved, so did the confidence of the interviewees and the information I sought.

\section{Participant Observation}

Participant observation is one of the most essential means of gathering data. Lofland and Lofland (1984) observed that participant observation:

Always involves the interweaving of looking and listening ... of watching and asking - and some of that listening and asking may approach or be identical to intense interviewing. Conversely, intensive interviewing studies may involve repeated and prolonged contact between researchers and informants, sometimes extending over a period of years, with considerable mutual involvement in personal lives - a characteristic often considered a hallmark of participant observation (p.13).

We assumed the role of a limited participant observer, which means "observing, asking questions, and building trust over time, but doesn't have a public role other than researcher" (p.94).

We observed and listened to what the two principals were saying and doing in their routine work related to HIV/AIDS. We attended Monday morning and Friday evening assemblies, rituals that are characteristic of secondary schools in Kenya. We were also allowed to attend staff meetings in the two schools. Although we had arranged with one head teacher to attend a Board of Management (BOM) meeting, it did not take off as was expected. Instead, we were invited to attend Parents Day activities, which usually occur in first term of every year as one of the critical decision-making body. As a former teachers, we can attest that these annual activities have symbolic significance. Each action, meeting, communication artifact, and policy offers a glimpse of meaning out of which stakeholders make sense. We utilize data from the principals' interviews and participant observer to offer a detailed account of what we saw, heard and observed which when analyzed is the eyes, ears, and perceptual senses for this study's readers.

\section{Data Analysis}

Data analysis started as soon as w entered the research field. This was through the observations we made of the school setting, structure, and student population. Qualitative research involves almost continuous and certainly progressive data analysis from the very beginning of data collection (Lincoln \& Guba, 1985). We used our experience with the first participant, to re-shape, re-phrase research questions, insights, ideas and views in order to refocus subsequent interviews and observations. To make my analysis meaningful, we use thick descriptions to capture my participants' experiences and narratives. According to Patton (2002), thick description:

Goes beyond mere fact and surface appearances. It presents detail, context, emotion, and the webs of social relationships that join persons to one another. Thick Description evokes emotionality and self-feelings. It inserts history into experience. It establishes the significance of and experience, or the sequence of events, for the 
person or persons in question. In thick description, the voices, feelings, actions, and meanings of interacting individuals are heard (p.503).

We also used participants' direct quotes to enrich emerging thematic concerns, analysis, and most importantly to capture them in their own terms in reporting the study findings. Direct quotations are a basic source of raw data in qualitative inquiry, revealing participants' depth of emotion, the ways they have organized their world, their thoughts about what is happening, their experiences, and their basic perceptions (Denzin \& Lincoln 2000).

HIV/AIDS is a disease, whose communication assumes the use of tacit language. Metaphors, analogies, and euphemistic phrases only understood to an insider are commonly employed when one makes reference to HIV/AIDS. This is very common in this study. Hardly is HIV/AIDS referred to by its real name, HIV/AIDS. It is shrouded in heightened language such as "list of shame" and "radio disease". We use the participants" metaphors, analogies, phrases, and concepts such as "Chill and seal", "selling wealthy to buy poverty", "we are family", great expectations, ruined hopes" and many others to accurately and sensitively analyze data and communicate the findings.

\section{Results/Findings}

We paint a brief portrait of each head teacher to give the reader a sense of their experiences, beliefs, social and economic settings of their schools, and the relationships between their schools, the community and other stakeholders. We used narrative portraits to capture their stories and voices. According to Lawrence-Lightfoot \& Davis (1997):

Portraiture is a method of inquiry that combines empirical description with aesthetic expression. Portraits are designed to capture the richness and complexity, and dimensionality of human experience in social and cultural context. It is meant to convey perspectives of the people who are negotiating those experiences (p. 3).

Due to the sensitivity of the topic, we used pseudonyms to protect the identity of the participants.

\subsection{Neema}

Neema was the principal of Hope Mixed Secondary School. While Neema had 15 years of experience as a principal of three precious secondary schools in the country, this was her first year at Hope Mixed Secondary School. The community had locked the previous principal out of the school because under his administration, students had not improved their academic performance in the national exams. Neema's priority therefore was to lay strategies that would improve Hope students' academic performance in national exams. Her school had 346 students, girls being the majority. The teaching staff consisted of 13 teachers amongst who were 3 on teaching practice (TP) and 2 employed by Board of Management (BOM). The government of Kenya through Teachers Service Commission (TSC) employs all trained teachers.

In Hope Mixed Secondary School, like in other schools where she was principal, the silence that pervaded Kisii community regarding HIV/AIDS and the tenacity of religious organizations to teach and "choose abstinence for the youth as the only way to prevent HIV" was annoying but not at all surprising to her. She confessed that coming from another ethnic community to head a school in Kisii community, she had a lot of learning and unlearning to do. Neema was married with 5 grown up children whom she had brought up in the Catholic Church and her only fear for them was dying of HIV/AIDS. "I don't fear my children dying of anything, I fear them dying of HIV/AIDS".

\subsection{Mr. Bidii}

Mr. Bidii was in his $14^{\text {th }}$ year as principal of Saba Mixed Day Secondary School. He hailed from the community where Saba Secondary school was located and commuted from his home. He said that he had taken over the leadership of the school 14 years ago when:

My predecessor was ejected out of this school for flimsy reasons. The parents came and put a padlock on his office and the church [Catholic Church] supported the parents' allegations. He was suspected of impregnating 2 school girls in a neighboring school, mismanaging school funds, and posting poor student performance (Bidii, Personal communication, July, 2019).

Mr. Bidii hailed from the local community and "as a catholic and a son of the soil', Saba Day BOM asked me to come home and help bring the school back to its feet", shared Mr. Bidii. Saba has 260 students and 10 teachers including 3 who were employed by BOM and hail from the local community. Mr. Bidii is a family man blessed with 6 children, with the eldest doing his 2nd year in a local university. He strongly believed in HIV/AIDS education programs that emphasize abstinence. His concern was the lack of resources and openness in discussing HIV/AIDS in the school and the local community.

\footnotetext{
${ }^{1}$ Heading a school in the same locality where one hails from is considered being a son of the soil
} 
Both principals decried the fast loss of teachers. In Neema's view, there are so many avenues in and outside the district that make teachers vulnerable. She narrated;

Teachers are human beings and so they get attracted. They are involved in school programs and activities that make them vulnerable. For instances, we have drama which necessitates them to be away from their families for some time. We have the marking of national exams, where we have couples during such times in the marking centers. This is where you find most teachers long for December when they can meet once again and express their emotions to each other. We have athletics, Drama, Music festivals all, which take away teachers from their spouses. These are avenues through which HIV/AIDS is suspected to be spreading among teachers in high numbers. The bulky of the working force in society is made of teachers. They have the finance; they are the rich people in rural parts, and so they can inherit as many widows as they can. Most teachers are infected, but they fear going to test to know their status, because we all carry our past with us. (Personal communication, June 2019).

Since the youth have always been said to be the group that is disproportionately affected by HIV/AIDS they are prime targets of most HIV/AIDS education programs in and outside school settings. The goal of HIV/AIDS education programs is to increase knowledge and skills needed for healthy relationships, effective communication and responsible decision-making that would protect learners from HIV infection, and to promote positive and responsible attitudes towards people living with HIV/AIDS. With this in mind, we asked Neema to describe how her students are impacted by HIV/AIDS, to which she said:

We deal with about 2 cases of infected students every year. The number of orphans is very high and keeps rising every year. For instance, in form 1, we have now 12 cases of orphans. Think of form $3 \mathrm{~s}$ and $4 \mathrm{~s}$. The whole school has an average of 80 students orphaned by HIV/AIDS and the number continues to rise every year. It is a sad situation because we know that there are schools that are worse than ours in the district. (Personal communication, June 2019).

Neema's vivid description of the number of infected and affected students in her school was indicative of what we thought was the case in other schools in rural Kisii district. We wondered of the number of young people who, because of poverty, could not afford to access secondary education. Based on the cases she had handled, Neema said that most student orphans struggle to survive not only at home, but also while in school. According to Mr. Bidii most of the orphans are not documented and so do not receive any systemic financial or social support network to help them in their struggles. The schools' reliance on student tuition to run its programs is not enough nor supposed to support needy cases. In a resigned way, Neema said, "We sympathize with these students, but sympathy alone will not help them. They need money to be in school, they need medication and food at home and they need to live the life of a teenager like any other teenager". To illustrate her point, Neema narrated a story of a boy in her school whose parents had died of what was suspected to be AIDs related illness.

We have one boy in form three who is the first-born in his family. Behind him are four other siblings. This boy plays all roles; mother, father, brother and a student to all four siblings. The uncles, who are expected to help, have isolated these children due to stigma. Their relatives are like 'they should not touch anything in our homes, they can infect the 'clean'. So, his family is viewed as a family of AIDS. You can imagine of a form three student struggling to fetch water, firewood, look for vegetables and cook for the family, and send the siblings to bed and he has to be in school at 7 in the morning. We keep counseling this boy and in some cases we give him some little financial support from our pockets to help him meet their immediate needs. He is always quiet and withdrawn. One time he came to school with his sickly young brother. He left the young brother by the gate and walked to school to report that today he will not be in school because he was taking his young sick brother to hospital. You can imagine the kind of society we live in (Personal communication, June 2019).

The above story almost brought Neema to tears. Her voice went dry several times as she described case after case of bright students who dropped out of school due to lack of financial support and the unwillingness of relatives to help. HIV/AIDS stigma and discrimination also is rife in this excerpt.

Neema confessed that she had confronted a senior teacher who was known to perpetuate what Neema called "a cultural cancer" that was taking the lives of many young people. Without mentioning names, she said that there was one senior teacher, "who is about to retire and continues to tell students that our culture is the best cure for HIV/AIDS. Observe our culture and religion and you will stop the spread of HIV/AIDS". This was the same message people spread in funerals and in the church. In her observation:

Culture is a stumbling block. We should put culture aside and empower our students with life saving information. Culture is not ashamed and does not die, but we get ashamed and die. What a shame to the people, to us who are caught in the snare of culture. We don't lose a finger or a lip if we tell our kids how to use condoms if they must have sex. Let us be ashamed after we have told our children and the students we teach the truth, the truth that will make them exercise informed choices and decisions about their lives. After all we are not going to put them on our back and get to know what they do every 
minute and second. It is a matter of life and death. (Personal communication, June 2019).

Neema's observation captures the reactive nature of the church and the local culture, which frustrated most schools' efforts to implement comprehensive prevention strategies to save the youth from sexually transmitted diseases including HIV. So, "we are always loud when mentioning abstinence and being faithful, but we mumble when it comes to condoms", she said. Talking about prevention from a realistic standpoint seemed to be held responsible for the breakdown of sexual morality. For Neema, the church believes that prevention of sexual immorality is abstinence. She feared loosing her job if she went against what the church prescribed as the only message that students must be taught in school and in church, abstinence.

Rarely does the church come in. Whenever it comes in during the teaching of HIV/AIDS, it insists that students and indeed all people must be taught according to our church doctrine. For instance, they insist on abstinence. If a teacher is found teaching contrary to this doctrine, they must go. It [the church] comes in to bury the dead. To pray for the dead if the dead used to go to their church. The schools are feeling the heat now. (Personal communication, June 2019).

While Neema acknowledged that religious organizations especially the Catholic church has great and persuasive force in the community including educational institutions, she simply didn't take serious, religious preaching of any sort as an effective way to preventing many young people from dying tragically at an early age from an infectious disease that could have been prevented. Her view augments Gould's (1993) that preaching total sexual abstinence to young people in the first and emotionally intense throes of adolescent sexuality is preaching a prescription of death.

\subsection{The less they know about sex the better}

According to Bidii, communication about HIV/AIDS issues to the extent that the church and local culture permitted, was manifested in school forums such as assemblies and staff meetings. He also said that his school utilizes resource people from either the Ministry of Health or NGOs operating locally to come and talk to students about HIV/AIDS. His other resource targets from the local community included a variety of local officials as AIDS educators, traditional healers, religious leaders, and leaders of local youth groups. Mr. Bidii does not believe in teaching students or allowing students to be taught about condoms use. He seemed to be very passionate about his belief that students "must wait until marriage to know about condoms. Talking about condoms does not allow us, as a school to provide especially to the youth necessary moral, social and spiritual preparation they need to navigate the social environment when they become of age". We inquired if the Catholic church, which sponsored his school subscribed to his opinion about condom use. He said:

Remember that ours is a Catholic-sponsored school. There are rules set by the dioceses about what we can teach or not teach. I believe you have heard of standoffs between a number of schools and their sponsor. Some of these cases have been in the newspapers. Just recently there was a standoff in our neighboring school between the principal and the sponsor. The principal had to be fired. It was alleged that he was encouraging students, I mean introducing the idea of condom use among students. This is not tolerated by the Catholic church here. So, in essence, we are not going to go out of our way to tell the students to use condoms because there are boundaries. Plus, my culture of our community won't let me go against it. (Personal communication, June 2019).

This excerpt is illustrative of the strong influence the Catholic church exerts in school leaders such as Mr. Bidii, who were complacent of researched-based HIV prevention methods.

Lack of an enforced education sector policy and guidelines on what or what should not be taught in schools seemed to contribute to Bidii's line of thinking. He indicated that even the integration of HIV/AIDS component in the national curriculum did not say at any point that students should be taught about condoms.

The emphasis is on abstinence and being faithful when they get married. Teachers feel pressed for time to talk about this and I feel they need to concentrate on examinable subjects. HIV/AIDS education is not a core subject, is not being tested. It is not a priority (Bidii, personal communication, June 2019).

Mr. Bidii further acknowledged that neither him nor parents communicated about cases of HIV/AIDS. However, they met in funerals, which happened almost every week in the community surrounding his school. Mr. Bidii further shared that he had, together with some prominent parents, church officials as well as local district education officials, attended two funerals of his own staff members and one for a student but never did he mention anything to do with HIV/AIDS even when he was certain that it was an AIDS-related case. Hence, "You will hardly find a parent or somebody coming to the office to talk about such case because people generally don't talk about it". According to him, a wall of silence seemed to be the norm in the community

The interview with Mr. Bidii elicited great confusion and epitomized the challenges principals experience in implementing HIV/AIDS education programs. The influence of the church in school management and its stance on HIV/AIDS prevention strategies is a challenge. Although one may view Bidii as a product of the cultural and religious influence, he had some understanding that knowledge, while not sufficient, is indispensable in preventing HIV/AIDS. Knowledge of how HIV/AIDS is contracted and prevented provides protection against 
individual vulnerability and gives the tools for understanding and avoiding risk (Kelly, 2002). It also creates a context in which the epidemic can be discussed and understood, and in which those infected and affected are cared for and included in society (UNAIDS, 2004). However, Mr. Bidii's personal opinion, the socio-cultural and religious contexts that fan the 'wall of silence' remain unchallenged and unchanged.

\section{Conclusion and Recommendations}

It will help to delocalize principals if sensitive matters that touch on the culture of communities where school are located ought to be implemented as envisioned. The cultural baggage of localized principals entraps them to articulate and implement research-based practices that have the potential to help young people in matters to do with HIV/AIDS prevention, including the use of condoms. Schools need to have greater cultural sensitivity to, and intimacy with the community, in order to push sensitive issues into a more open and frank discourse.

In a world fraught with HIV/AIDS and with an enhanced risk of HIV infection, schools can no longer deliver a strictly health-based message about AIDS in traditional ways. Kelley (1990) observes that HIV/AIDS programs should focus on the individual as well as the context upon which the individual functions. Such programs should be integrated in health children and health schools and should cover issues ranging from reproductive health, sexuality, gender, sex education as well as STIs and condoms use. Issues such as discrimination and human rights, respect for women and the information and life skills particularly needed by girls in the context of HIV/AIDS should also be part of the prevention strategies. These programs should be implemented by appropriate and trained teachers and a greater variety of "teacher" role models, peers, traditional healers, priests and imams, politicians, families, and schools.

As Jonathan Mann said in 1998, at the International AIDS Conference in Geneva, Switzerland, "Our responsibility is historic, for when the history of AIDS and the global response is written, our most precious contribution may well be that at the time of plague we did not flee, we did not hide, and we did not separate ourselves." This is my signature today but will be my practice tomorrow.

\section{References}

Bennell, P. (2003, December). The Impact of the AIDS Epidemic on Schooling in Sub-Saharan Africa. Background Paper for the Biennial Meeting of the Association for the Development of education in Africa.

Bennell, P., K. \& Hyde, A. L., (2002). The impact of the HIV/AIDS epidemic on the education sector in SubSaharan Africa: a synthesis of the findings and recommendations of three country studies. Sussex, Centre for International Education University of Sussex Institute of Education.

Black, J., \& Jones, J. (1988). HIV infection: Educational programs and policies for school personnel. Journal of School Health 58(8): 317-322

Bogdan, R., \& Biklen, S. K. (1982). Qualitative research for education: an introduction to theory and methods. Boston, Allyn and Bacon.

Boler, T. \& Aggleton, P. (2005). Life skills education for HIV prevention: a critical analysis Save the Children and ActionAid International. Retrieved from http://www.campaignforeducation.org/resources/Feb2005/life_skills_paper.pdf

Boler, T. \& Carroll, P. (2004) Addressing the Educational Needs of Orphans and Vulnerable Children. Save the Children and ActionAid. from http://www.aidsconsortium.org.uk/Education/educationworkinggroup.html.

Boler, T., \& Ibrahim, A. (2003). The sound of silence: difficulties in communicating on HIV/AIDS in schools. ActionAid. Retrieved from: http://www.actionaid.org.uk/798/hivaids.html.

Boler, T., \& Jellema, A. (2005). Deadly inertia: A cross-country study of educational responses to HIV/AIDS. Brussels. Global Campaign for Education

Bollinger, L. K., \& Cooper-Arnold, C. (2004). Where are the gaps? The effects of HIV-prevention interventions on behavioral change. Studies in Family Planning 35(1): 27-38.

Bolman, L. G., \& Deal, T. E. (2017). Reframing organizations: Artistry, choice and leadership. San Francisco, CA: John Wiley \& Sons, Inc.

Coombe, C. (2000). Managing the impact of HIV/AIDS on the education sector in South Africa. Paper commissioned by United Nations Economic Commission for Africa (UNECA) in preparation for the Africa Development Forum 2000. Addis Ababa, UNECA

Coombe, C. (2002). HIV/AIDS and Trauma among Learners: Sexual Violence and Deprivation in South Africa. In J. G. Maree \& L. Ebersohn (Eds.). Lifeskills within the Caring Professions: A Career Counselling Perspective for the Bio-technical Age. Cape Town: Heinemann Educational Publishers.

Coombe, C., \& Kelly, M. J. (2001). Education as a Vehicle for Combating HIV/AIDS. Prospect XXXI(3): $435-$ 445.

Creswell, J. W. (1998). Qualitative inquiry and research design: choosing among five traditions. Thousand Oaks, CA: Sage Publications. 
Denzin, N. K. \& Lincoln, Y. S. (2000). Handbook of qualitative research. Thousand Oaks, CA: Sage Publications.

Ennew, J., \& Akunga, A. (2000). The impact of HIV/AIDS on education in Kenya and the potential for using education in the widest sense for the prevention and control of HIVIAIDS: a Government of Kenya and UNICEF Kenya Country Office study: final report, November 2000. Nairobi, Kenya.

Fisher, A. A., \& Foreit, J. R. (2002). Designing HIV/AIDS intervention studies: an operations research handbook. New York, NY: Population Council.

Gachuhi, D. (1999). The impact of HIV/AIDS on education systems in the Eastern and Southern Africa Region, and the response of education systems to HIV/AIDS: Life Skills programmes. Prepared for UNICEF ESARO and presented to All Sub-Saharan Africa Conference on Education for All (EFA), Johannesburg, December

Glesne, C. (1999). Becoming qualitative researchers: an introduction. New York, Longman.

Gubrium, J. F., \& Holstein, J. A. (2002). Handbook of interview research: context \& method. Thousand Oaks, CA: Sage Publications.

Haffner, D. (1996). Sexual health for America's adolescents. Journal of school Health 66(4): 151-152

Haignere, C., \& J. Culhane, J. (1996). Teachers' receptiveness and comfort teaching sexuality education and using non-traditional teaching strategies. Journal of School Health 66(5): 140-144.

https://www.unaids.org/en/regionscountries/countries/kenya

Kelly, M. J., \& International Institute for Educational Planning. (2000a). Planning for education in the context of $H I V-A I D S$. Paris, Unesco, International Institute for Educational Planning (IIEP). Retrieved from http://unesdoc.unesco.org/images/0012/001224/122405e.pdf

Kirby, D. (1994). School-based programs to reduce risk behaviors. A review of effectiveness. Public Health reports 109(3): 339-3361.

Kirby, D. (1995). Sex and HIV/AIDS education in schools have a modest but important impact on sexual behavior. British Medical Journal 3(11) p. 402

Kirby, D. R., \& Barth, A., (1991). Reducing the Risk: Impact of A New Curriculum on Sexual Risk-taking. Family Planning Perspective 23(6): 253-263

Kvale, S. (1996). Interviews: an introduction to qualitative research interviewing. Thousand Oaks, CA: Sage Publications.

LeCompte, M. D. \& Schensul, J. J. (1999). Analyzing \& interpreting ethnographic data. Walnut Creek, CA: AltaMira Press.

LeCompte, M. D., \& Schensul, J. J. (1999). Analyzing \& interpreting ethnographic data. Walnut Creek, CA: AltaMira Press.

Lincoln, Y. S., \& Guba, E. G. (1985). Naturalistic inquiry. Beverly Hills, CA: Sage Publications.

Lofland, J., \& L. Lofland, L. H. (1984). Analyzing social settings: a guide to qualitative observation and analysis. Belmont, CA: Wadsworth Publications.

Maanen, J. V. \& Barley, S. R. (1985). Cultural organization: Fragments of a theory In P. J. Frost (Ed). Organizational Culture. Beverly Hills, Sage: pp.31-53.

Maanen, J. V., \& Barley, S. R. (1985). Cultural Organization: Fragments of a Theory. In P. J. Frost et al. Organizational Culture. Beverly Hills, Sage: pp.31-53.

Masland, A. T. (1985). Organizational culture in the study of higher education. Review of higher Education 8: $157-168$

Miles, M. B., \& Huberman, A. M. (1994). Qualitative data analysis: An expanded sourcebook. Thousand Oaks, Sage Publications.

Ministry of Education, Kenya (2001). Report of the second National HIV/AIDS/STDs Conference. Lessons Learned. October 1999. Nairobi: NASCOP.

Morgan, G. (1997). Images of organization. Thousand Oaks, CA: Sage Publications.

Ongaga, K., \& Ombonga, M. (2018). Students perceptions of school-based HIV/AIDS education programs in Western Kenya. Journal of Education and Practice. 9(33), 42-52.

Patton, M. Q. (2002). Qualitative research and evaluation methods. Thousand Oaks, CA: Sage Publications.

Person, J. \& Marin, G. (1988). Issues in Prevention of AIDS among Black and Hispanic men. American Psychologist 43(11): 871-877

Postrado, L. T., \& Nicholson, H. (1992). Effectiveness in delaying the initiation of sexual intercourse of girls aged 12-14: Two components of the Girls Incorporated Preventing Adolescent Pregnancy Program. Youth and Society 23(3): 356-379.

Schenker, I. (2001). New Challenges for School AIDS Education within an evolving HIV Pandemic. Prospect $X X X I(3): 415-434$

Schenker, I., \& Greenblatt, C. (1993). Israeli youth and AIDS: knowledge and attitude changes among high school students following an AIDS education program. Israel Journal of Medical Sciences 29(10): 41-47. 
Sherman, R. R. and R. B. Webb (1988). Qualitative research in education: focus and methods. NY, NY: Falmer Press.

Shuey, D. (1999). Increased sexual abstinence among in-school adolescents as a result of school health education in Soroti District, Uganda. Health Education Research 14(3): 411-419.

Siamwiza, R. (1999). A Situation analysis of policy and teaching HIV/AIDS prevention in educational institutions in Zambia. Paper prepared for the UNESCO/UNAIDS Project on Integrating HIV/AIDS Prevention in School Curricula. Lusaka, Zambia.

Spradley, J. P. (1979). The ethnographic interview. Fort Worth, NY: Harcourt Holt Rinehart \& Winston.

UNAIDS (2018). Factsheet. Retrieved from https://www.unaids.org/en/resources/fact-sheet

UNAIDS (2019). Country Statistics. Retrieved

Valerio, A., \& Bundy, D. (2004). Education and HIV/AIDS: A sourcebook of HIV/AIDS Prevention Programs. Washington, D.C: World Bank.

White, D. M., \& Ballard, J. (1993). The status of HIV/AIDS education in the professional preparation of preservice elementary teachers. Journal of Health Education 24(2): 68-72.

Wolcott, H. (1988). Ethnographic research in education. In R. Jaegger (Ed.). Complementary methods for research in art education (pp. 187-206). Washington, DC: American Education Research Association.

World Bank, \& NetLibrary Inc. (2002). Education and HIV/AIDS a window of hope. Washington, DC, World Bank.

Yin, R.K. (2003). Case study research: Design and methods. Thousand Oaks, CA: Sage.

Table 1

Study Participants

\begin{tabular}{|l|c|l|c|c|c|}
\hline \multicolumn{1}{|c|}{ Name of School } & Name of Head Teacher & \# of Students & \multicolumn{2}{|c|}{ \# of Teaching staff } & $\begin{array}{c}\text { Sponsor of } \\
\text { the school }\end{array}$ \\
\hline $\begin{array}{l}\text { Hope Mixed Sec. } \\
\text { School }\end{array}$ & Ms. Neema & 346 & Trained & Untrained & $\begin{array}{l}\text { Lutheran } \\
\text { Church }\end{array}$ \\
\cline { 1 - 1 } $\begin{array}{l}\text { Saba Mixed Day Sec. } \\
\text { School }\end{array}$ & Mr. Bidii & 260 & 8 & 5 & \\
\hline
\end{tabular}

